\title{
Regulatory evaluation of Glybera in Europe - two committees, one mission
}

Daniela Melchiorri, Luca Pani, Paolo Gasparini, Giulio Cossu, Janis Ancans, John Joseph Borg, Catherine Drai, Piotr Fiedor, Egbert Flory, Ian Hudson, Hubert G. Leufkens, Jan Müller-Berghaus, Gopalan Narayanan, Brigitte Neugebauer, Juris Pokrotnieks, Jean-Louis Robert, Tomas Salmonson, and Christian K. Schneider

Representing the first gene therapy to be approved in the Western world, alipogene tiparvovec (Glybera; Uniqure) has recently been said to have had a "substantial impact from a regulatory perspective" (Nature Rev. Drug Discov. 11, 664; 2012) ${ }^{1}$. The therapy was granted marketing authorization in the European Union for the treatment of lipoprotein lipase deficiency, which results in a clinically heterogeneous condition with a risk of potentially life-threatening pancreatitis $^{2}$, at the end of 2012. The decision followed a positive opinion by the European Medicines Agency (EMA)'s Committee for Medicinal Products for Human Use $(\mathrm{CHMP})^{3}$, and a previous recommendation of the EMA's Committee for Advanced Therapies (CAT) $)^{4,5}$.

The approval process for Glybera was extensively discussed in the scientific community, sometimes critically ${ }^{6-12}$. During the process, the opinions of the CHMP and the CAT differed: although the opinion of both committees was originally negative, in a "re-examination procedure" the opinion of the CAT became positive $e^{5}$, whereas the CHMP maintained its negative opinion ${ }^{13}$. However, both committees finally recommended approval of the medicine. As regulators who have been involved in this approval process, we would like to provide insight into why the Glybera procedure was challenging, and give assurance to the scientific community regarding confidence in both orphan drug and gene therapy regulation in Europe.

\section{The approval process for Glybera}

In Europe, gene therapies undergo a centralized approval procedure via the EMA. For advanced therapy medicinal products (ATMPs), which include gene therapies, the CAT as an expert committee first performs a scientific assessment of the application dossier and prepares a draft opinion on its approvability for a final decision by the CHMP, a committee with considerable long-term expertise, which also ensures consistency in the opinions.

The assessment process for Glybera was long and complex owing to multiple reasons. These included the complexity of the product class for which there was little previous regulatory experience (this was the first procedure for a gene therapy to correct a genetic deficiency); the long product development time, during which science evolved and specific regulatory requirements were about to be established; the complex disease scenario (a very rare disease) with a fluctuating clinical outcome (pancreatitis); and the fact that the company was small with academic origins (as usually also seen for other ATMPs) $)^{14}$.

The applicant's total clinical programme included 27 patients with lipoprotein lipase deficiency on a low-fat diet ${ }^{2}$. At first, the main measure of efficacy was based on a reduction in blood triglyceride levels. However, this was later changed to postprandial chylomicrons, as this biomarker was thought to more specifically address the pharmacodynamic effect of Glybera, whereas the effect on triglyceride levels was only short-lived. This raised additional issues during the scientific review: were the data robust enough for a previously non-validated biomarker (postprandial chylomicrons) in the presence of more inconclusive clinical evidence (pancreatitis)? Should data from that biomarker be accepted as pivotal evidence for activity, as it was scientifically better fitted to measure the treatment effect (as recommended by an ad hoc scientific advisory group to the CAT and CHMP) than the one originally defined in the protocol (triglyceride levels)? Or should one rather focus on that (formally failed) primary end point? There were only a handful of patients from the study population for whom such data on the newly proposed biomarker were available, and even fewer for a sustained period.

Although different opinions were issued by the two committees during the procedure, both committees were consistent in their scientific judgement when the details were considered. The CHMP acknowledged the promising nature of the data by an almost unprecedented "positive tone" when drafting its initial negative opinion, so as to demonstrate that it would be prepared to reconsider the case once more specific and supportive data had been collected (and here the vast majority of the CHMP agreed). The CHMP was clearly of the view that development should continue. We consider that both committees had already, at that time, taken major steps towards finding a way for ATMPs to be used for the treatment of very rare diseases, by considering all data rather than single outcome measures. Both committees considered that evolution of scientific knowledge can make the appreciation of an emerging, biologically more plausible biomarker necessary, if well justified and supported by data. Both committees were well aware that the acceptance of a limited data set was a double-edged sword, as it could be perceived as lowering the standards. However, this was not the case: both committees agreed that the limited clinical efficacy and safety data set needed to be supplemented by additional data.

The opinion of the two committees differed on the stage at which such additional data should be submitted: before approval (as initially preferred by the CHMP) or after approval (as recommended by the CAT). It is important to note that the final positive outcome was, to a major extent, also driven by an appreciation of the specific clinical scenario of lipoprotein lipase deficiency. Assessing orphan drugs in 'ultra-rare' conditions (here defined as a prevalence of less than 1 in 100,000) was not new to the CHMP; several drugs are already licensed for conditions with such low prevalence (FIG. 1). However, all of these conditions follow either a continuously progressive course of deterioration or a very active disease course if left untreated (TABLE 1). The effect of a therapeutic intervention for such conditions is therefore easier to measure within a relatively short timeframe.

Furthermore, surrogate markers for clinical outcome existed for these conditions (TABLE 1). By contrast, lipoprotein lipase deficiency results in pancreatitis in otherwise often phenotypically healthy individuals - a complication that is not 




Figure 1 | Authorized orphan drugs and ultra-orphan conditions. Orphan conditions with authorized treatments (at least one per condition) are ordered by prevalence (number of patients per 10,000 in the European Union). Analysis from data on file at the European Medicines Agency (EMA; cut-off: November 2012); in situations where a condition was listed more than once (and with varying prevalence), the lowest prevalence was listed. Ultra-rare conditions (the boxed indications in the figure) were defined as having a prevalence of equal to or less than 0.1 per 10,000 persons in the European Union. Lipoprotein lipase deficiency, targeted by Glybera (alipogene tiparvovec), represents the third rarest disease for which a medical treatment has so far been authorized. The pivotal data submitted for these ultra-rare conditions are listed for comparison in TABLE 1. ALL, acute lymphoblastic leukaemia; CEL, chronic eosinophilic leukaemia; CFTR, cystic fibrosis transmembrane conductance regulator; HPC, haematopoietic progenitor cell; $\mathrm{Ph}+$, Philadelphia chromosome positive; SGCA, subependymal giant cell astrocytoma. *Treatment in patients who require intrathecal analgesia. ${ }^{\ddagger}$ With platelet-derived growth factor receptor $(P D G R)$ gene rearrangements. ${ }^{\S} \mathrm{C} 1$ esterase inhibitor deficiency. 
Table 1 | Pivotal data for authorized treatments in ultra-rare conditions*

\begin{tabular}{|c|c|c|c|c|c|c|c|}
\hline $\begin{array}{l}\text { Authorized } \\
\text { therapeutic } \\
\text { indication }\end{array}$ & $\begin{array}{l}\text { Prevalence } \\
\text { (per } \\
10,000)\end{array}$ & $\begin{array}{l}\text { Medicinal } \\
\text { product } \\
\text { (generic } \\
\text { name) }\end{array}$ & $\begin{array}{l}\text { Date of } \\
\text { marketing } \\
\text { authorization }\end{array}$ & End points used & $\begin{array}{l}\text { Duration } \\
\text { of pivotal } \\
\text { study }\end{array}$ & $\begin{array}{l}\text { Size of } \\
\text { pivotal } \\
\text { study or } \\
\text { studies }\end{array}$ & $\begin{array}{l}\text { Disease } \\
\text { characteristics }\end{array}$ \\
\hline $\begin{array}{l}\text { Splenomegaly in } \\
\text { myelofibrosis }\end{array}$ & 0.01 & $\begin{array}{l}\text { Jakavi } \\
\text { (ruxolitinib) }\end{array}$ & $23 / 08 / 2012$ & $\begin{array}{l}\text { Number of patients with } \\
\geq 35 \% \text { spleen volume } \\
\text { reduction at week } 24\end{array}$ & 24 weeks & 219 & $\begin{array}{l}\text { Progressive } \\
\text { disease } \\
\text { (haematological) }\end{array}$ \\
\hline $\begin{array}{l}\text { Lipoprotein lipase } \\
\text { (LPL) deficiency }\end{array}$ & 0.02 & $\begin{array}{l}\text { Glybera } \\
\text { (alipogene } \\
\text { tiparvovec) }\end{array}$ & $25 / 10 / 2012$ & $\begin{array}{l}\text { Reduction in fasting } \\
\text { plasma triglyceride levels; } \\
\text { additional end points } \\
\text { included chylomicron- } \\
\text { related end points and } \\
\text { reduction in frequency } \\
\text { and/or severity of clinical } \\
\text { signs and symptoms related } \\
\text { to LPL deficiency including } \\
\text { pancreatitis }\end{array}$ & $\begin{array}{l}\text { N/A } \\
\text { (variable) }\end{array}$ & 14 and 5 & $\begin{array}{l}\text { Fluctuating } \\
\text { clinical course } \\
\text { (metabolic) }\end{array}$ \\
\hline Hunter syndrome & 0.02 & $\begin{array}{l}\text { Elaprase } \\
\text { (idursulfase) }\end{array}$ & 08/01/2007 & $\begin{array}{l}\text { 6-minute walk test, } \\
\text { percentage predicted FVC } \\
\text { (baseline to week 53) }\end{array}$ & 12 months & 96 & $\begin{array}{l}\text { Progressive } \\
\text { disease (organ } \\
\text { impairment) }\end{array}$ \\
\hline $\begin{array}{l}\text { Mucopolysaccha- } \\
\text { ridosis VI }\end{array}$ & 0.024 & $\begin{array}{l}\text { Naglazyme } \\
\text { (galsulfase) }\end{array}$ & $24 / 01 / 2006$ & $\begin{array}{l}\text { 12-minute walk test over } \\
\text { time (week } 6,12,18,24)\end{array}$ & 24 weeks & 39 & $\begin{array}{l}\text { Progressive } \\
\text { disease (organ } \\
\text { impairment) }\end{array}$ \\
\hline $\begin{array}{l}\text { Mucopolysaccha- } \\
\text { ridosis I }\end{array}$ & 0.025 & $\begin{array}{l}\text { Aldurazyme } \\
\text { (laronidase) }\end{array}$ & $10 / 06 / 2003$ & $\begin{array}{l}\text { 6-minute walk test, } \\
\text { percentage predicted FVC } \\
\text { (baseline to week 26) }\end{array}$ & 26 weeks & 45 & $\begin{array}{l}\text { Progressive } \\
\text { disease (organ } \\
\text { impairment) }\end{array}$ \\
\hline Fabry disease & 0.027 & $\begin{array}{l}\text { Fabrazyme } \\
\text { (agalsidase } \\
\text { beta) }\end{array}$ & 03/08/2001 & $\begin{array}{l}\text { Reduction of GL3 } \\
\text { accumulation from the } \\
\text { capillary endothelium of } \\
\text { the kidney to score } 0 \text { at } \\
\text { week } 20\end{array}$ & 20 weeks & 58 & $\begin{array}{l}\text { Progressive } \\
\text { disease (organ } \\
\text { impairment) }\end{array}$ \\
\hline $\begin{array}{l}\text { Cryopyrin- } \\
\text { associated periodic } \\
\text { syndromes (CAPS) }\end{array}$ & 0.05 & $\begin{array}{l}\text { Ilaris } \\
\text { (canakinumab) }\end{array}$ & 23/10/2009 & $\begin{array}{l}\text { Proportion of patients } \\
\text { with disease flare in part II } \\
\text { (randomized withdrawal) }\end{array}$ & $\begin{array}{l}48 \text { weeks } \\
\text { (three } \\
\text { parts) }\end{array}$ & 35 & $\begin{array}{l}\text { Active } \\
\text { inflammatory } \\
\text { clinical course }\end{array}$ \\
\hline $\begin{array}{l}\text { Cryopyrin- } \\
\text { associated periodic } \\
\text { syndromes (CAPS) }\end{array}$ & 0.05 & $\begin{array}{l}\text { Arcalyst } \\
\text { (rilonacept) }\end{array}$ & 23/10/2009 & $\begin{array}{l}\text { Mean change from baseline } \\
\text { to end point in the mean } \\
\text { key symptom score } \\
\text { (both parts of study) }\end{array}$ & 48 weeks & 47 & $\begin{array}{l}\text { Active } \\
\text { inflammatory } \\
\text { clinical course }\end{array}$ \\
\hline $\begin{array}{l}\text { Adrenal cortical } \\
\text { carcinoma }\end{array}$ & 0.1 & $\begin{array}{l}\text { Lysodren } \\
\text { (mitotane) }\end{array}$ & $28 / 04 / 2004$ & $\begin{array}{l}\text { Bibliographical evidence } \\
\text { ( } 220 \text { articles) with various } \\
\text { end points including } \\
\text { survival, remission time } \\
\text { and tumour size reduction }\end{array}$ & $\begin{array}{l}\text { N/A } \\
\text { (variable) }\end{array}$ & $\begin{array}{l}\text { N/A }(\sim 500 \\
\text { patients } \\
\text { overall) }\end{array}$ & $\begin{array}{l}\text { Progressive } \\
\text { disease (cancer) }\end{array}$ \\
\hline $\begin{array}{l}\text { Hereditary } \\
\text { tyrosinaemia type } 1\end{array}$ & 0.1 & $\begin{array}{l}\text { Orfadin } \\
\text { (nitisinone) }\end{array}$ & $21 / 02 / 2005$ & $\begin{array}{l}\text { Data from a compassionate } \\
\text { use programme including } \\
\text { survival, survival without } \\
\text { transplantation, death } \\
\text { due to liver failure, } \\
\text { transplantation due } \\
\text { to liver failure and } \\
\text { hepatocellular carcinoma. }\end{array}$ & $\begin{array}{l}\text { N/A } \\
\text { (variable) }\end{array}$ & $\sim 207$ & $\begin{array}{l}\text { Progressive } \\
\text { disease } \\
\text { (metabolic) }\end{array}$ \\
\hline $\begin{array}{l}\text { Paroxysmal } \\
\text { nocturnal } \\
\text { haemoglobinuria }\end{array}$ & 0.1 & $\begin{array}{l}\text { Soliris } \\
\text { (eculizumab) }\end{array}$ & 20/06/2007 & $\begin{array}{l}\text { Haemoglobin stabilization } \\
\text { and units of PRBCs } \\
\text { transfused during the } \\
\text { treatment phase }\end{array}$ & 26 weeks & 88 & $\begin{array}{l}\text { Active disease } \\
\text { requiring regular } \\
\text { intervention }\end{array}$ \\
\hline
\end{tabular}


Table 1 (cont.) | Pivotal data for authorized treatments in ultra-rare conditions*

\begin{tabular}{|c|c|c|c|c|c|c|c|}
\hline $\begin{array}{l}\text { Authorized } \\
\text { therapeutic } \\
\text { indication }\end{array}$ & $\begin{array}{l}\text { Prevalence } \\
\text { (per } \\
10,000)\end{array}$ & $\begin{array}{l}\text { Medicinal } \\
\text { product } \\
\text { (generic } \\
\text { name) }\end{array}$ & $\begin{array}{l}\text { Date of } \\
\text { marketing } \\
\text { authorization }\end{array}$ & End points used & $\begin{array}{l}\text { Duration } \\
\text { of pivotal } \\
\text { study }\end{array}$ & $\begin{array}{l}\text { Size of } \\
\text { pivotal } \\
\text { study or } \\
\text { studies }\end{array}$ & $\begin{array}{l}\text { Disease } \\
\text { characteristics }\end{array}$ \\
\hline $\begin{array}{l}\text { Lambert-Eaton } \\
\text { myasthenic } \\
\text { syndrome }\end{array}$ & 0.1 & $\begin{array}{l}\text { Firdapse } \\
\text { (amifampridine) }\end{array}$ & 23/12/2009 & $\begin{array}{l}\text { Bibliographical evidence } \\
\text { with two main studies; } \\
\text { end point measurements } \\
\text { included various } \\
\text { neurological scores } \\
\text { including measurements } \\
\text { of neurological disability } \\
\text { score, muscle strength, } \\
\text { electrophysiological } \\
\text { measurements, or the } \\
\text { quantitative myasthenia } \\
\text { gravis score }\end{array}$ & $\begin{array}{l}15 \text { days } \\
\text { and } 6 \text { days }\end{array}$ & 12 and 26 & $\begin{array}{l}\text { Progressive } \\
\text { disease } \\
\text { (neurological) }\end{array}$ \\
\hline $\begin{array}{l}\text { Atypical haemolytic } \\
\text { uremic syndrome } \\
\text { (aHUS) }\end{array}$ & 0.1 & $\begin{array}{l}\text { Soliris } \\
\text { (eculizumab) }\end{array}$ & $24 / 11 / 2011$ & $\begin{array}{l}\text { Platelet change } \\
\text { from baseline and } \\
\text { haematological } \\
\text { normalization (study 1), } \\
\text { and TMA Event-Free } \\
\text { status and haematological } \\
\text { normalization from } \\
\text { baseline (study 2) }\end{array}$ & 26 weeks & 17 and 20 & $\begin{array}{l}\text { Progressive } \\
\text { disease (organ } \\
\text { impairment) }\end{array}$ \\
\hline
\end{tabular}

only influenced by various factors including diet, but that also exhibits a much more unpredictable and fluctuating disease course with intermittent healthy periods. Therefore, it would - in theory - be necessary to conduct either a large clinical study enabling for a sufficiently high event rate (which is not feasible for an ultra-rare disease) or a long follow-up in order to detect a sufficient number of events in a smaller patient population (how long would be feasible in a pre-approval situation?). So, to counterbalance the inherent limitations of the clinical database, an approval "under exceptional circumstances" 15 with post-approval supplementation of the database was the most appropriate route.

\section{The way forward}

In our view, the message to the scientific community is positive: both committees had complementary approaches. They delivered within the spirit of the legislation and took a scientific approach recognizing the rarity of the disease and the difficulties in obtaining comprehensive data. They acknowledged the evolution of science and considered the data as a whole. It is common in science that in borderline situations two experts can reach different conclusions when balancing certainties and uncertainties. However, this balanced and weighted scientific view of both committees, as briefly highlighted here, resulted in a seemingly 'black and white' outcome, as for a regulatory opinion there are only two possible decisions (positive or negative), and only this was visible to the scientific community.

During the approval procedure the two committees closely collaborated, and they will continue to strengthen their collaboration based on increasing experience. This will be facilitated by the recent inauguration of the EMA Scientific Coordination Board ${ }^{16}$, which involves all chairpersons of the EMA committees. We do not agree that this is "the perfect bureaucratic response" 17 , as it is not another committee that complicates procedures but a body that takes a more strategic and coordinative role under the umbrella of the EMA's missions and visions. Its creation is not a consequence of the Glybera procedure, but a logical step towards the fulfilment of the EMA's goal to ensure efficient operation of its core business - principles that were already published in early 2011 (REF. 18).

The role of the CAT was recently challenged $^{6-12}$, given that the CHMP is required by legislation to make the final opinion. This may be perceived as though the CAT is not heard, or that it lacks the power to foster innovation and create a fruitful environment for its stakeholders to develop and gain the approval of ATMPs. However, this assumption is not only incorrect but 
also oversimplified. Besides the fact that the CHMP fully supports innovation, the CAT has considerable influence at the early stage of ATMP development, for example, by systematically reviewing and discussing the CHMP's scientific advice procedures for ATMPs, by participating in the innovation task force meetings concerning ATMPs at the EMA, or when issuing certificates on quality and/or non-clinical data. The approach that the legislator had taken when drafting the ATMP regulation was not intended to separate the licensing procedure for ATMPs from that of other human medicines; it would be difficult to explain to patients why an ATMP should have a different standard compared to a conventional medicine, and it would not be helpful to exclude the CHMP's extensive experience of reviewing dossiers including those for drugs targeting rare diseases.

In conclusion, we submit that both committees' deliberations and conclusions illustrate their openness towards innovative approaches to drug development and their willingness to exercise flexibility where scientifically appropriate. The history summarized above also provides a reminder of the regulators' challenge to balance early availability of promising treatments with a need to uphold appropriate standards of evidence, and in borderline situations a different opinion of independent experts can never be fully excluded. We contend that a 'black and white' view of the regulatory procedure for Glybera (or any other similar scenario), as has been expressed in the literature, is not correct; rather, the opinions of the two committees illustrate the shades of grey involved in such procedures and also highlight the shared dedication of the committees to patients and innovation.

Daniela Melchiorri is at the Department of Physiology and Pharmacology, the University of Rome "Sapienza", P.le Aldo Moro 5, 00185 Rome, Italy: she is also a member of the Committee for Medicinal Products for Human Use (CHMP) at the European Medicines Agency (EMA), 7 Westferry Circus, Canary Wharf, London E14 4HB, UK.

Luca Pani is at the Italian Medicines Agency (Agenzia Italiana del Farmaco), Via del Tritone, 181, 00187 Rome, Italy; he is also a member of the Committee for Medicinal Products for Human Use (CHMP) at the European Medicines Agency (EMA), 7 Westferry Circus, Canary Wharf, London E14 4HB, UK.

Paolo Gasparini is at the University of Trieste (Medical Genetics), Via dell'Istria 65, 34100, Trieste, Italy; he is also a member of the Committee for Advanced Therapies (CAT) at the European Medicines Agency (EMA), 7 Westferry Circus, Canary Wharf, London E14 4HB, UK.
Giulio Cossu is at the Department of Cell and Development Biology, University College London, 21, University Street, London WC1E 6BT, UK; he is also a member of the Committee for Advanced Therapies (CAT) at the European Medicines Agency (EMA), 7 Westferry Circus, Canary Wharf, London E14 4HB, UK.

Janis Ancans is at the University of Latvia (Faculty of Biology), Kronvalda Blvd. 4, LV-1586 Riga, Latvia; he is also a member of the Committee for Advanced Therapies (CAT) at the European Medicines Agency (EMA), 7 Westferry Circus, Canary Wharf, London E14 4HB, UK

John Joseph Borg is at the Medicines Authority of Malta, 203, Level 3, rue D'Argens, Gzira 1368, Malta; he is also a member of the Committee for Advanced

Therapies (CAT) and the Committee for Medicinal Products for Human Use (CHMP) at the European Medicines Agency (EMA), 7 Westferry Circus, Canary Wharf, London E14 4HB, UK.

Catherine Drai is at the European Medicines Agency (EMA), 7 Westferry Circus, Canary Wharf, London E14 4HB, UK

Piotr Fiedor is at the The Warsaw Medical University (Department of General and Transplantation Surgery), Nowogrodka 59, 02-006 Warsaw, Poland: at the Office for Registration of Medicinal Products, Medical Devices and Biocidal Products, ul. Zabkowska 41, 03-736 Warsaw, Poland Warsaw, Poland; and he is a member of the Committee for Medicinal Products for Human Use (CHMP) at the European Medicines Agency (EMA), 7 Westferry Circus, Canary Wharf, London E14 4HB, UK.

Egbert Flory is at the Paul-Ehrlich-Institut, Paul-Ehrlich-Strasse 51-59, D-63225 Langen, Germany; he is also a member of the Committee for Advanced Therapies (CAT) at the European Medicines Agency (EMA), 7 Westferry Circus, Canary Wharf, London E14 4HB, UK.

Ian Hudson is at the Medicines and Healthcare products Regulatory Agency (MHRA), 151 Buckingham Palace Road, Victoria, London SW1W 9SZ, UK; he is also Vice-Chair of the Committee for Medicinal Products for Human Use (CHMP) the European Medicines Agency (EMA), 7 Westferry Circus, Canary Wharf, London E14 4HB, UK.

Hubert G. Leufkens is at the Medicines Evaluation

Board (CBG-MEB), Graadt van Roggenweg 500 , 3531 AH Utrecht, The Netherlands; at the Utrecht Institute for Pharmaceutical Sciences (UIPS), PO Box 80 082, 3508 TB Utrecht, The Netherlands; he is also a member of the Committee for Medicinal

Products for Human Use (CHMP) at the European Medicines Agency (EMA), 7 Westferry Circus, Canary Wharf, London E14 4HB, UK.

Jan Müller-Berghaus is at the Paul-Ehrlich-Institut, Paul-Ehrlich-Strasse 51-59, D-63225 Langen, Germany; he is also a member of the Committee for Medicinal Products for Human Use (CHMP) and the Scientific Advice Working Party (SAWP) at the European Medicines Agency (EMA), 7 Westferry Circus, Canary Wharf, London E14 4HB, UK.

Gopalan Narayanan was previously at the Medicines and Healthcare products Regulatory Agency (MHRA), 151 Buckingham Palace Road, Victoria, London SW 1 W 9SZ, UK; and he was also a member of the Committee for Advanced Therapies (CAT) and the Scientific Advice Working Party (SAWP) at the European Medicines Agency (EMA), 7 Westferry Circus, Canary Wharf, London E14 4HB, UK
Brigitte Neugebauer is at the European Medicines Agency (EMA), 7 Westferry Circus, Canary Wharf, London E14 4HB, UK.

Juris Pokrotnieks is at the Medical Faculty, Riga Stradinš University, 16 Dzirciema Street, Riga LV-1007, Latvia; he is also a member of the Committee for Medicinal Products for Human Use (CHMP) the European Medicines Agency (EMA), 7 Westferry Circus, Canary Wharf, London E14 4HB, UK.

Jean-Louis Robert is at the Laboratoire National de Santé, Service du Contrôle des Médicaments, 1 A rue A Lumière, 1011 Luxembourg, Luxembourg; he is also the Chair of Quality Working Party (OWP), a member of the Committee for Advanced Therapies (CAT) and of the Committee for Medicinal Products for Human Use (CHMP) at the European Medicines Agency (EMA), 7 Westferry Circus, Canary Wharf, London E14 4HB, UK.

Tomas Salmonson is at the Medical Products Agency, Dag Hammarskjölds väg 42, 75103 Uppsala, Sweden; he is also Chair of the Committee for Medicinal Products for Human Use (CHMP) at the European Medicines Agency (EMA), 7 Westferry Circus, Canary Wharf, London E14 4HB, UK.

Christian K. Schneider is at the Danish Health and Medicines Authority, Axel Heides Gade 1, DK-2300 Copenhagen, Denmark; at the Twincore Centre for Experimental and Clinical Infection Research, Feodor-Lynen-Strasse 7,

D-30625 Hannover, Germany; and he is also Chair of the Committee for Advanced Therapies (CAT) at the European Medicines Agency (EMA), 7 Westferry Circus, Canary Wharf, London E14 4HB, UK.

Correspondence to C.K.S e-mail: CHSC@dkma.dk doi: 10.1038/nrd3835-c1 Published online 19 August 2013

1. Flemming, A. Regulatory watch: pioneering gene therapy on brink of approval. Nature Rev. Drug Discov. 11, 664 (2012).

2. European Medicines Agency. European public assessment report (EPAR) for Glybera (alipogene tiparvovec). European Medicines Agency [online], http://www.ema.europa.eu/docs/en_GB/document library/EPAR - Public assessment report/ human/002145/WC500135476.pdf(2012).

3. European Medicines Agency. European Medicines Agency recommends first gene therapy for approval. European Medicines Agency [online], http://www.ema. europa.eu/docs/en GB/document library/Press release/2012/07/WC500130146.pdf(2012).

4. European Medicines Agency. Questions and answers: positive opinion on the marketing authorisation of Glybera (alipogene tiparvovec). European Medicines Agency [online], http://www.ema.europa.eu/docs/en GB/document library/Medicine_QA/2012/07/ WC500130153.pdf (2012).

5. European Medicines Agency. Monthly report: Committee for Advanced Therapies October 2011 meeting. European Medicines Agency [online], http://www.ema.europa.eu/docs/en_GB/document library/Committee meeting_report/2011/10/ WC500116979.pdf (2011).

6. English, V. Commentary: Glybera - when the experts disagree. MedNous http://www.mednous.com/news/ commentary-glybera-when-experts-disagree (9 Nov 2011).

7. Dimond, P. F. Latest gene therapy disapproval points to confusion over regulatory setup. Genetic Engineering \& Biotechnology News, Insight \& Intelligence http://www.genengnews.com/ keywordsandtools/print/3/25046 (15 Nov 2011).

8. Miller, N. Glybera and the future of gene therapy in the European Union. Nature Rev. Drug Discov. 11, 419 (2012).

9. Moran, N. The EMA's shambolic handling of Glybera. BioWorld Perspectives. http://bioworld.blogs.bioworld. com/2012/05/07/the-emas-shambolic-handling-ofglybera (2012). 